
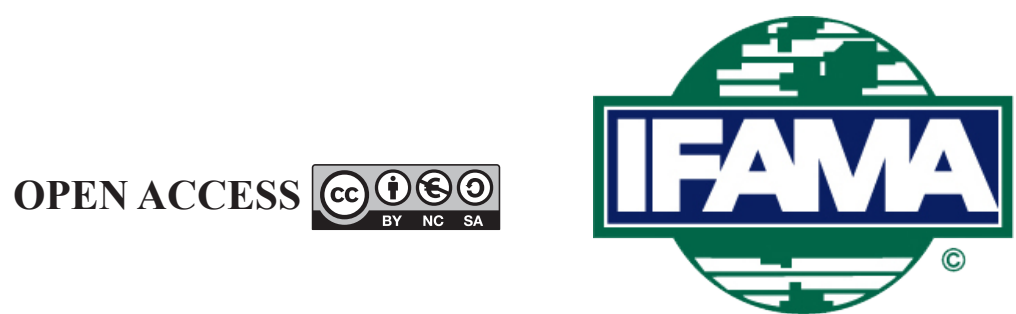

International Food and Agribusiness Management Review

Volume 23, Issue 1, 2020; DOI: 10.22434/IFAMR2018.0108

Received: 4 October 2018 / Accepted: 11 June 2019

\title{
The role of multinational corporations in local dairy value chain development: case of Friesland Campina WAMCO (FCW) in Nigeria RESEARCH ARTICLE
}

\author{
Ogbuagu Ekumankama ${ }^{\mathrm{a}}$, Abel Ezeoha ${ }^{\mathrm{b}}$ and Chibuike Uche ${ }^{(\mathrm{IC}}$ \\ ${ }^{a}$ Principal Lecturer, Federal Polytechnic, Banking and Finance, Nasarawa, Nigeria \\ ${ }^{b}$ Professor, Department of Economics (Department of Banking and \\ Finance), Ebonyi State University, 053 Abakaliki, Nigeria \\ cProfessor, African Studies Centre, Leiden University, The Netherlands
}

\begin{abstract}
Nigeria is arguably the largest importer of dairy products in Africa. Available statistics shows that up to $98 \%$ of the total dairy products consumed in the country are imported; and that about $75 \%$ of the entire dairy market is controlled by FrieslandCampina WAMCO (FCW). The purpose of this study is to examine the basis for the prevailing import orientation in the dairy industry since 1973. Is the orientation traceable to operations of multinational companies or the institutional and governance challenges in the country? Using triangulated data collected from FCW official reports and other relevant sources, and a content analytical technique, the study finds that the problem in the industry is multifaceted. Central to the challenges are persistent institutional and infrastructural defects, as well as faulty integration designs adopted by FCW. Based on this, the paper recommends that reversing the current trend requires government's policies that dis-incentivizes importation. However, such policies can work only when the right atmosphere for cattle farming and local dairy production is put in place.
\end{abstract}

Keywords: FrieslandCampina, MNCs, dairy industry, local value chain, integration, government policies, Nigeria.

JEL code: Q11, Q12, Q13, Q18

${ }^{\oplus}$ Corresponding author: c.uche@ascleiden.nl 


\section{Introduction}

The dairy industry in Nigeria provides an interesting premise for studying the microcosm of multinational business engagements in Africa. This is especially with respect to examining the dynamics and consequences of the spatial difference between sources of production inputs and multinational business interests. Right from the colonial era, the industry has remained foreign-oriented in terms of the sources of its raw material and semi-finished factor inputs (Nwoko, 1988). This has effectively constrained the development of the local value chain and the delivery on the developmental mandate of employment creation and skills transfer (Okojie, 2018). A dominant thesis in the literature is that the preference of dairy multinational companies (MNCs) for imported factor inputs can be explained by the persistent weakness in the governance and regulatory institutions, as well as the increasing costs of doing business in Nigeria (The Economist, 2015). For the MNCs, importation of non-mineral inputs, semi-finished and finished goods thus become a popular business strategy. The implication is that over the past years, local production systems are either non-existent or poorly integrated into the global business value chain.

The failure of the local value chain to contribute meaningfully to national development manifests in the persistence of cluttered livestock enterprise - in the form of transhumance pastoralism. Not only does transhumance pastoralism bring about low cow milk production, its traditional practice has also been threatened by climate change and Fulani Herdsmen insurgency. Increasing incidence of climate change induces a north-to-south migration of cattle farmers in desperate search for grazing grounds beyond their traditional home-grounds. Such southward movement has brought about incessant clashes and escalation of tensions between herdsmen and grazing communities, which in turn makes the business of cow breeding and herding very primitive and risky. This is also coupled with the difficulty imposed by the dearth of basic infrastructure like roads, electricity, and reticulated water supply across the length and breadth of the country, which makes milk collection and processing highly inefficient.

A number of government programmes designed to encourage local dairy value chain development and make the country self-sufficient in milk production yielded little results. The recent attempt to develop cattle colonies in all regions of the country to quell herdsmen insurgence and boost milk production, for instance, was met with stiff community resistance (Akinnaso, 2018). The colonies, according to the country's agricultural minister, are designed to enable the herdsmen 'feed their livestock', without having 'to disturb the fertile agricultural lands that belong to farming communities' (Orji, 2018). Government programmes in this direction, even in cases where they were not resisted, failed to make any meaningful impact in the development of local dairy productive capacity. Instead, the dairy industry remains dominated by a few dairy MNCs, which though incorporated as manufacturing outfits, are more inclined to practices that allow them import finished and semi-finished dairy products through their global value chains. While this strategy undoubtedly serves the profit interests of the MNCs, local dairy production remains undermined. The status quo raises questions as to: how the MNCs survived for so many years working contrary to national development goals? By what mechanisms are they able to resist government-backed backward integration policies?

These questions, no doubt, bother on the theoretical contestation around the operations of MNCs in Africa. On one side, the argument is that MNCs bring development to their host economies, and so should be supported and incentivized by the government (Asiedu, 2002; Iamsiraroj, 2016). On the other hand, they are despised as western tools for exploitation and expropriation (Carmody, 2017; Udofia, 1984). Local production capacities flourish in industrial sectors where the operations of MNCs are backwardly integrated into the local dairy value chain. On the other hand, the capacity is compromised where MNCs practice forward integration that allows them to import factor inputs and semi-finished products from their global value chain actors.

Although reliance on importation is considered part of the attempts by the MNCs to preserve positive profits amidst local production challenges, the actions of the MNCs under such circumstance have equally been linked to increased rent-seeking behaviour and other forms of manipulative practices (Deininger and Binswanger, 1995). It is equally the prevalent of forward integration practices among MNCs that brought 
about the accusation of MNCs influencing national policies and regulations as a protection over their rentseeking behaviour (Zhu, 2017), and of using corporate social responsibilities (CSR) as a tool for mitigating arising hostility risks (Aqueveque et al., 2018).

While this kind of theoretical contestation dominate public debate about the role of MNCs in the development of Africa's local industrial bases, few case-by-case evidence exist in the literature to explain its microcosmic nature. Previous studies tend to broadly link MNCs to practices that widen the spatial distance between their commercial interests and the development needs of their host economies (Phelps, 2008). Such studies however suffer from generalization bias, by failing to identify the specificities of multinational business actions and the consequences of such in the development of local value chains. As an attempt to close this gap, our study makes use of the case of FrieslandCampina WAMCO (henceforth FCW) operations in Nigeria. The FCW case allows us to explore key issues relating to the extent to which the operations of MNCs converge or diverge from the host country's local value chain; and the justifications for the back-and-forth shift in integration policies among MNCs.

Our choice of FCW is informed by the fact that the company controls about $75 \%$ of dairy market in Nigeria, which arguably is the largest importer of dairy products in Africa. Nigeria imports about $98 \%$ of the total dairy products consumed in the country (Punch Newspaper, 2016a) and spends an average of US $\$ 1.3$ billion yearly on such importation (Business Day, 2019). This statistics confirms that the successes recorded by FCW in the industry can largely be attributed to its import operations. Given its long years of operations in Nigeria, the FCW case study enriches debate on the paradox of multinational business survival in turbulent business environment. What is today known as FCW was incorporated in Nigeria as the West African Milk Company Nigeria Limited (WAMCO) in 1973 and as private limited liability company for the manufacture, processing, packing and distribution of various dairy products in the country. Prior to the establishment of FCW, FrieslandCampina products were already being exported to Nigeria. Its most popular product in Nigeria - Peak Milk - was first sold in the country in 1954 (FrieslandCampina, 2011).

\section{Theoretical contestation and the context of diary production in Nigeria}

\subsection{The theoretical contestation}

The primary goal of import substitution industrialization strategies, in most countries where they are practice, is to deepen domestic production and reduce dependency on importation (Adewale, 2017). In pursuance of this goal, countries institute different incentive and protection schemes designed to guarantee local industry development. For foreign firms operating in the affected countries, the expectation is that they would be able to contribute towards developing the local industrial bases and by so doing generate some welfare economic gains in the forms of employment generation, skills transfer, and increased local productivity. In most of the countries, particularly those in Africa, this expectation is hardly met. MNCs in such environment have instead been accused of pursuing profit interests in a way that runs contrary to host government's industrial development agenda, leaving most of the countries in chronically debased industrial condition (Gui-Diby and Renard, 2015). Weak industrial base makes countries vulnerable to chronic import dependency, even in sectors where they are abundantly endowed with the requisite raw materials (Gui-Diby and Renard, 2015; Taylor, 2016).

Under such circumstance, MNCs are usually left with two options, to organize transactions vertically within their internal structures or horizontally within the market structure (Geyskens et al., 2006; Madhok, 1997). Although the classical transaction cost theory assumes that the market structure is a more efficient option for organizing transactions (Coase, 1937; Williamson, 1981), the preference, in the case of MNCs' operations, is weakened by the fact that being foreign imposes higher transaction costs (Hennart, 1991). This is in addition to the fact that in some developing countries, preference for internalization (vertical integration) is heightened by high level of informality in the source markets and the associated contract uncertainty (Geyskens et al., 2006; Wiesner, 2017). Studies have shown that the extent a firm can go in achieving sustainable vertical 
integration depends on the strength of the governance institutions, availability of supportive infrastructure, and the conduciveness of the policy and regulatory environments.

In the absence of viable government incentives and supports, as in the case of Nigeria, MNCs tend to disconnect themselves from the more expensive and less efficient local value chain, and to use their stronger market power to manipulate governments' policy directives in favour of liberalization policies that encourage importation (Kapfer, 2006). In Nigeria, high defragmentation of the local input sources makes any form of horizontal integration outside of the MNCs near impossible; and the absence of strong institutions (e.g. effective property rights enforcement) imposes extra costs against any single MNCs relying on local production inputs. The environment of business transactions in the country is largely uncertain and risky, and policy instability raises the risk of expropriation.

The relevant institutional frameworks in place to address the problem of expropriation are either weak or deliberately undermined. In such environment, rent-seeking characterizes the behaviour of MNCs and other large-scale firms (Acemoglu and Robinson, 2010). The tendency of MNCs indulging in rent-seeking to offset high cost of transaction increases to a scale that can undermine local production (Auty, 2007). Sustaining this rent-seeking behaviour as a strategy for profit maximization leads MNCs into seeking influence in the policy making and legislative processes, at the detriment of local value chain development (Lodge, 2018; Zhu, 2017). Along this line, therefore, our study hypothesizes that the persistent underdevelopment of the Nigerian local dairy value chain is traceable to rent-seeking practices by the dominant MNCs in the dairy industry.

\subsection{Background issues in milk production in Nigeria}

To understand the challenges and opportunities inherent in the Nigerian dairy industry, there is need to first analyse the peculiarities in the industry, especially with reference to the historical attempts at its development, government policy actions, and multinational agribusiness activities. The very nature of the industry in Nigeria creates strong incentives for foreign businesses with well developed global value chain, while at the same time constituting drawbacks against the development of the local dairy industry. That the Nigerian government has over the past years done little to correct the imbalances raises issues as to whether the unproductive nature of the dairy value chain is attributable to the activities of foreign firms or the constrains that characterise the country's business environment.

In the business of dairy farming and processing, the Nigerian market is arguably the most fragmented. Up to $95 \%$ of all locally produced milk in the country come from smallholder farmers, with little progress made in the areas of cooperative formation, commercial dairy farming and milk production. Although the country is among the top 15 countries in terms of the population of cows according to the 2013 FAO World Cattle Inventory (Figure 1), milk production in the country stands at barely one litre of milk per day per cow. Even the minimal milk production takes place in the remote rural areas with no linkage, no access road, no water, and no electricity. This means that the little milk produced locally hardly gets to the urban markets where it is mostly needed (Nwoko, 1988). The disconnection between rural production and urban market implies that rising prices and marginal gains in the urban market do not significantly impact the prices of rural dairy products - thus providing additional crowding out effect against local production. Urban plants do not also source milk from local producers because the transaction cost of doing so is enormous. In the words of one of the operators, for instance:

Three or four years ago we used to fly our milk down to Lagos...It cost a fortune. The milk would spoil sitting in the airport. We had to pay off customs. It was a nightmare. Nowadays, the firm uses costly refrigerated trucks instead. Drivers must brave day-long journeys on disintegrating roads. Each truck requires about 200,000 naira $(\$ 1000)$ in opaque license fees every month

(The Economist, 2015). 


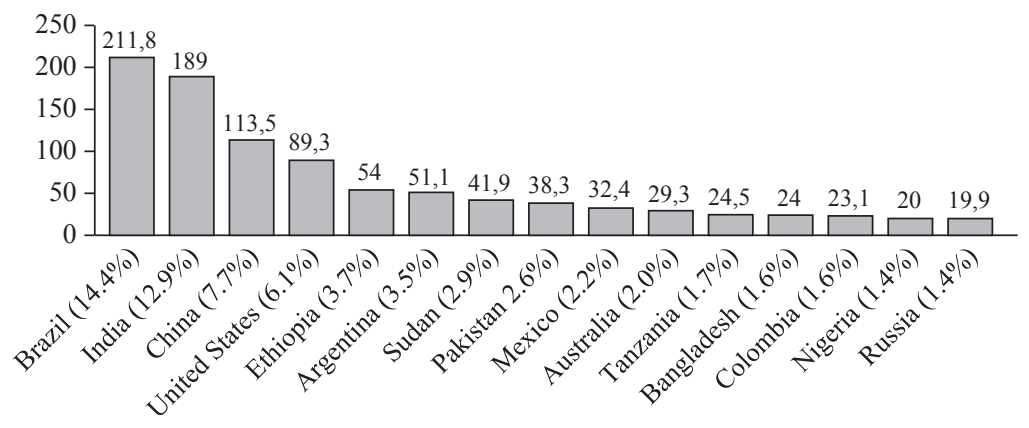

Figure 1. Top 15 countries based on FAO World Cattle Inventory (in millions and percentages of the world) (FAOSTAT, 2013).

Skewed spatial distribution of dairy cow and the large size of Nigeria's population arguably makes the country the largest untapped dairy markets in Africa. Dairy farming and pasturing is seen largely in the country as an exclusive occupational preserve of the Fulanis in the rural parts of Northern Nigeria (Sutter, 1987). Unsuccessful efforts by the government to link the rural dairy markets to the more advanced (though import-dependent) urban markets were largely due to the high costs of transacting along the local value chain. Unfortunately, those earlier efforts were marred by government policy inconsistency vis-à-vis the removal of import restrictions on imported dairy products (Nwoko, 1988), and the adoption of a structural adjustment programme (SAP) in 1986. SAP led to the influx of cheaper imports with price advantage over locally produced milk (Jansen, 1992). Since the abolition of SAP in 1996, no further policy effort was made by the government to either protect or incentivize local milk production.

Private sector efforts at repositioning the dairy industry are also less impactful, largely because milk and other dairy products importation favour the few MNCs that control the Nigerian market (Ilu et al., 2016). This claim is supported by the evidence shown in Table 1, which indicates that FCW and five other foreign firms control up to $99 \%$ of the entire dairy market. Incidentally, these foreign firms are importing and selling processed dairy products, or at best importing milk powder and reconstituting it into liquid milk and other dairy products such as yoghurt, ice cream and confectioneries (Ilu et al., 2016).

Ironically, for as long as the status quo remained, the Nigerian government thought it less desirable to come up with any coherent policy for local dairy development (McCulloch et al., 2017; Jansen, 1992). At best, the only known explicit dairy industry regulation in the country is the yet-to-be-passed Milk and Dairy Products Regulations 2018, drafted by the country's National Agency for Food and Drug Administration and Control (NAFDAC). The proposed regulation is limited only to ensuring that "no milk or dairy products shall be manufactured, imported, exported, advertised, sold or distributed in Nigeria, unless it has been registered in accordance with the provisions of these Regulations' (NAFDAC). There is nothing in the regulation to either deter milk importation or incentivize domestic production.

Table 1. Market share of dairy companies in Nigeria (based on 2016 retail value RSP) (PCW, 2017).

\begin{tabular}{llc}
\hline Companies & Home country & Shares \\
\hline FrieslandCampina WAMCO Nigeria Plc & The Netherlands & $74.5 \%$ \\
Nutricima Pz & The United Kingdom & $7.0 \%$ \\
National Food Industries Co Ltd & Saudi Arabia & $5.1 \%$ \\
Sosaco Nigeria Ltd & India & $4.8 \%$ \\
CHI Ltd & The Netherlands & $4.0 \%$ \\
PZ Industries Plc & The United Kingdom & $3.5 \%$ \\
Others & Not specific & $1.0 \%$ \\
Total & & $100 \%$ \\
\hline
\end{tabular}




\subsection{Evidence on the integration role of multinational companies in the diary business}

A number of factors combine to determine the extent to which the operations of MNCs can contribute to the development of their host economies. First is the degree of integration and cooperation with indigenous business operators. Evidence from Dries et al. (2009) reveals that an integration approach that supports the flow of raw materials and other factor inputs from local businesses to MNCs can yield the desired benefits of skills transfer and productive employment creation. Essentially, effective integration offers MNCs opportunities to provide strategic bridging between the markets and the local smallholder farmers (Chagwiza et al., 2016; Sharma et al., 1994). On the other hand, poor integration results to a situation where the presence and the operations of foreign firms crowd out local businesses, essentially due to the latter's inability to meet with higher standards and market imperfections (Dries and Swinnen, 2004; Murigu et al., 2018).

Secondly, government interventions can aid the achievement of 'an appropriate balance between inter-company coordination (to protect the investments of large firms from opportunistic activity by smaller competitors) and competition (to promote efficiency and equitable prices paid to smallholders)' (Poulton et al., 2006). Herath and Weesink (2009), in the case of the Sri Lankan Tea Sector, showed how government intervention was able to reduce transaction cost and improve coordination arrangements within the sector. Specifically, government policies and interventions can incentivize MNCs to support local businesses, which have been proven in the cases of countries with strong government dairy development incentives (see for instance Dries and Swinnen, 2004). On the other hand, absence of effective government intervention, in the East African region, was identified by Omondi et al. (2017) as being key among the problems militating against dairy sector innovation and development.

Thirdly, in an economy dominated by struggling small and informal businesses, the activities of MNCs face greater antagonisms, which in turn constrains the role of the latter in local economic development. When the number of small local suppliers is high and their locations disperse, foreign investors tend to switch relationship to a handful of concentrated large-scale suppliers as a strategy for minimizing transaction costs - an approach that is proven to be responsible for the rapid exclusion of many small suppliers (Dries and Swinnen, 2004). Under this circumstance, MNCs perceive their relationship with local businesses not as a partnership model, but as a social responsibility model.

By examining an integration effort of a multinational company in the presence of complexities such as poor infrastructure, and absence of supportive government policies and interventions, this paper presents a new insight to investors, policymakers, and researchers. Central to this insight is the need for rethinking, in a mutually benefiting manner, the link between MNC operations and local dairy value chain development in Africa.

\section{The Friesland Campina Case}

\subsection{Sources and methods of data collection}

The unit of our data collection and case analysis is FCW and its Dairy Development Programme (DDP) in Nigeria. The programme was initiated in August 2010 as the first practical attempt at mainstreaming smallholder cattle farmers into the national dairy value chain. According to information contained in the programme's website, its focus is 'on sharing knowledge and expertise by means of training, knowledge partnerships and initiating and supporting projects aimed at improving the dairy farming infrastructure' (FrieslandCampina,. 2019). The company's DDP is accepted by the Nigerian government as a viable model for developing the dairy sector in the country. Its implementation was claimed to have earned FCW the prize of being the best CSR Company in West Africa in 2015 (Punch Newspaper, 2016b).

Our field data collection took place between 2016 and 2017. In line with Kilelu et al. (2017), we used mixed data collection method so as to triangulate the information and enhance the validity of our analytical 
procedure and reliability of the study outcomes. Annual reports and official releases of FCW were among the major sources of data used for the analysis. Another source of data applied was a focus group discussion, based on a stakeholders' advocacy workshop organized from $29^{\text {th }}$ June to $1^{\text {st }}$ July 2016. The participants covered dairy farmers from three states in the South Western part of Nigeria (made up of Ondo, Oyo, and Osun states), representatives from a cross-section of industries operating within the dairy value chain, and representatives from relevant government agencies. The workshop provided opportunity for face-to-face interaction and cross-fertilization of diverging positions among the relevant stakeholders.

There was also a dairy farmers' questionnaire specifically designed to elicit qualitative data from predominantly illiterate cattle breeders and dairy farmers. A total of 250 local dairy farmers who officially identified with the DDP of FCW were contacted through hired field assistants. Due to the limited literacy of the sampled farmers, only about 102 copies of the questionnaire were returned and used for our analysis. Although the return rate at about $41 \%$ is low, we do not consider that a problem due to the homogenous nature of the population of local dairy farmers. All the respondents were smallholders, none having more than 50 cattle heads. None also was an active member of any cooperative society, which depicts a clear lack of horizontal coordination among the local dairy farmers. Finally, a structured interview guide was used to collect data from the R\&D/Dairy Development Unit of FCW, which was meant to provide deeper insights and clarifications on some of the claims raised in the company's annual reports.

\subsection{Procedure for data analysis}

Specifically, we collected qualitative data on the institutional and infrastructural challenges constraining local value chain development in Nigeria, the nature of vertical integration practiced by FCW, and the structural defects in the DDP integration model. Using these information, we examined the existence or otherwise of rent-seeking behaviour in the dairy industry, the extent to which FCW participate in the formulation and enforcement of dairy policies and regulations in the country, the role of government in the promotion of local dairy chain, and the extent to which the FCW's operations have affected local value chain development.

The analytical procedure adopted in the study is described in this section. In line with the requirements of triangulated research design, data collected from the four sources, most of which were qualitative, were compared to determine whether the claims were converging, contrasting, or complementary. We compared information collected from the company's internal records (annual reports, structured interview, and official press releases) with those from external sources (e.g. smallholder dairy farmers, focus group discussion, and media reports). We grouped data arising from the annual reports and the interview with R\&D/Dairy Development Unit of FCW in the same category to depict the official claims and positions of FCW. The converging views from these two sources were then benchmarked with the issues and concerns raised by stakeholders during the focus group discussion, as well as the opinions from the cattle farmers' questionnaire. The results are as provided in the following section.

\subsection{Findings and discussion}

Findings from our triangulated sources generally reveal the persistent institutional and infrastructural challenges facing the local dairy industry in Nigeria, the widening distance between FCW operations and the smallholder dairy farmers in the local diary value chain, and the failed attempts at using DDP to mainstream smallholder farmers into the formal dairy value chain. In this section, we discuss the findings along these lines.

\section{- The institutional and infrastructural challenges}

Findings from our analysis confirm the dominant thesis that major problem militating against the development of local dairy industry is the weakness in the existing institutional and infrastructure frameworks in the country, which allow a status quo that is detrimental to local production. Results from our triangulated data indicate that lack of basic infrastructure essentially makes it difficult for the development of a large market 
for fresh milk in Nigeria. The same infrastructural deficiencies also complicate the processing of fresh milk in the country. The FCW's 1997 annual report confirms that 'there are still many hurdles to the distribution of our farm fresh dairy products.' Confirming this, about $89 \%$ of the rural farmers who participated in the survey acknowledged not having idea of any government agricultural policies that had benefited them directly. Lack of basic amenities such as water and access to road is among the three factors that featured most frequently in the cattle farmers' list of areas for assistance (Table 2). Others are healthcare for their cattle, and creation of more milk collection centres to further ease access.

We discovered, for instance, that from the beginning, FCW had its dairy farm in Jos (North central Nigeria), where its milk products produced in the farm were sold under the 'farm fresh' label. Due to distance and the absence of good transport and storage systems, it was however difficult to integrate the output of the company's dairy farm in Jos into its milk processing facilities based in Lagos. Siting of the dairy farm at Jos is no doubt ideal as it allowed FCW proximity to greater population of local dairy farmers in the North. However, coordinating farming in the north and processing in the south proved financially unviable due to infrastructural challenges. Jos to Lagos is approximately 1000 kilometres. Without functional road, air or rail transport system, such coordination is rendered near impossible. A alter attempt by FCW to commercialize the farm was justified by an acknowledgement in the company's annual report that the scheme 'has been very costly considering the time and resources spent so far'. Commercializing of the farm however did little to improve its financial situation, due largely to high transaction costs.

\section{- Lack of effective integration}

Findings from our study also show that from inception, the operations of $\mathrm{FCW}$ were loosely integrated into the local dairy value chain, and that there was no consistent effort by government to change this pattern. The $\mathrm{R} \& \mathrm{D} /$ Dairy Development manager in FCW had contended during our interview that despite the efforts of the company at enhancing the local value chain in the dairy industry, between 60 to $80 \%$ of the raw materials needed by WAMCO are imported, with a caveat that water, which constitutes a major component in dairy products was included as raw materials. A PricewaterhouseCoopers report corroborated this by emphasizing that FCW sourced only 3\% of milk inputs form the local markets in 2016 (PWC, 2017). This trend, the report attributed to regulatory challenges, institutional constraints and the absence of government support, which forced the company to shift from backward to forward integration strategy. The shift was responsible for the collapse of the dairy farm programme and eventual return to the core business of importing powdered milk and reconstituting such into various milk products. That FCW could be allowed full grip of the market with imported milk and dairy products (Cf. Ilu et al., 2016) eventually became the basis for the Dutch parent

Table 2. Responses of the dairy farmers on the benefits and gaps in the dairy development programme. ${ }^{1}$

\begin{tabular}{lll}
\hline Programme element & Benefits & Areas of further assistance \\
\hline - Milk collection* & - Increased income* & - Provision of basic amenities such as water and \\
- Artificial insemination & - Job creation* & access roads from farms to the milk collection \\
and feeding* & - Training & centres* \\
& - Improved milk yields* & - Access to soft loans \\
& - Improved milk quality and & - Provision of cross-breeding and exotic breeds \\
& - Impriene & - Government interventions and assistance \\
& dairy farming* & - Free healthcare for the cows \\
& & - Creation of additional milk collection centres \\
& closer to the farmers* \\
& - Provision of dams for grazing \\
& - Provision of means of transportation such as \\
& easier bikes
\end{tabular}

\footnotetext{
$1 *$ dairy farmers' responses that occurred most frequently.
} 
company's consistent increase in its shareholding in the Nigerian subsidiary. The shareholding was, for example, increased from 51\% in 1997 (WAMCO, 1997) and to 67.81\% in 2015 (FrieslandCampina, 2015).

In defense of its forward integration approach, the R\&D/Dairy Development Manager maintained that Nigeria was a risky country for doing business, hence the focus on short-term investment strategy. Evidence from the FCW annual report validates this claim by emphasizing that to 'limit these risks as far as possible FCW follows an active dividend policy in relation to these subsidiaries' (FrieslandCampinat, 2014). Such dividend policy has resulted to a situation where the company has actively paid all its profits as dividends (Figure 2). Given its perception of the Nigerian business environment being risky, it became unlikely that the company would undertake investments with long term gestation in the country, and that it could unlikely reverse its dependence on imported raw materials.

The emergence of the DDP, which is similar to the Laiterie Du Berger (LDB)'s milk supply chain in Senegal (Wang et al., 2017) and the dairy hub framework uner the East African Dairy Development project (Rao et al., 2016), thus became a coping strategy for FCW (FrieslandCampina, 2011) to quell protest from local farmers and divert government's attention from the needs of local value chain development.

\section{- The dairy development programme model}

The DDP case validates the claim that the operations of FCW are loosely integrated, and that the absence of government intervention in the industry provide excusable basis for the importation of dairy products in the country. The company's DDP was started in August 2010 as the first practical attempt at streamlining and developing the dairy farming sector in the country. Greater percentage of the DDP operations is concentrated in the South Western states to maintain proximity to Lagos, the operational headquarters of Friesland Campina. This design of the programme again implicates the insincerity of motives on the side of FCW. It points at an attempt to widen (rather than shrink) the spatial distance between its operational focus and the host country's development goal.

Although the programme is designed to link independent smallholder cattle breeders to the milk collection facilities established by FCW, its concentration in the South Western region of the country runs contrary to the fact that greater percentage of the smallholder cattle farmers are located in the Northern region. The distance between cattle breeders and FCW milk collection centres, as illustrated in Figure 3, are further widened by the infrastructural challenges earlier discussed. Also, locating the facilities in the Southern region meant that a greater percentage of the smallholder farmers are automatically excluded from the scheme. It is therefore not surprising that the DDP model of intervention struggled to succeed under the conditions on which it was implemented.

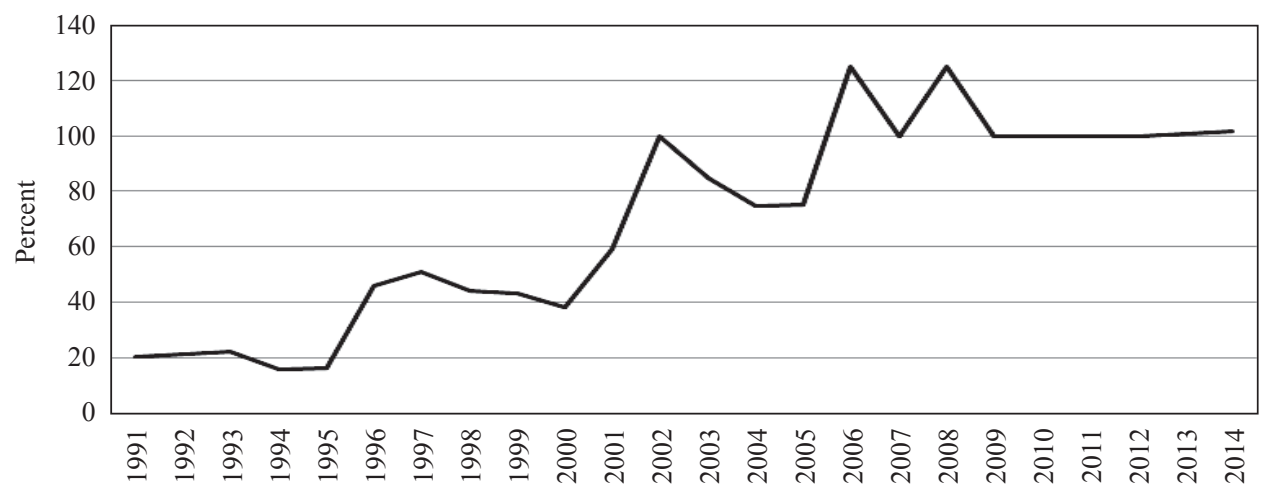

Figure 2. Friesland Campina WAMCO (FCW) dividend profit after tax ratio. Computed from FCW annual reports (FCW, 2010, 2014; Friesland Food WAMCO Nigeria Plc., 2000, 2005; WAMCO, 1995, 1997, 2000). 


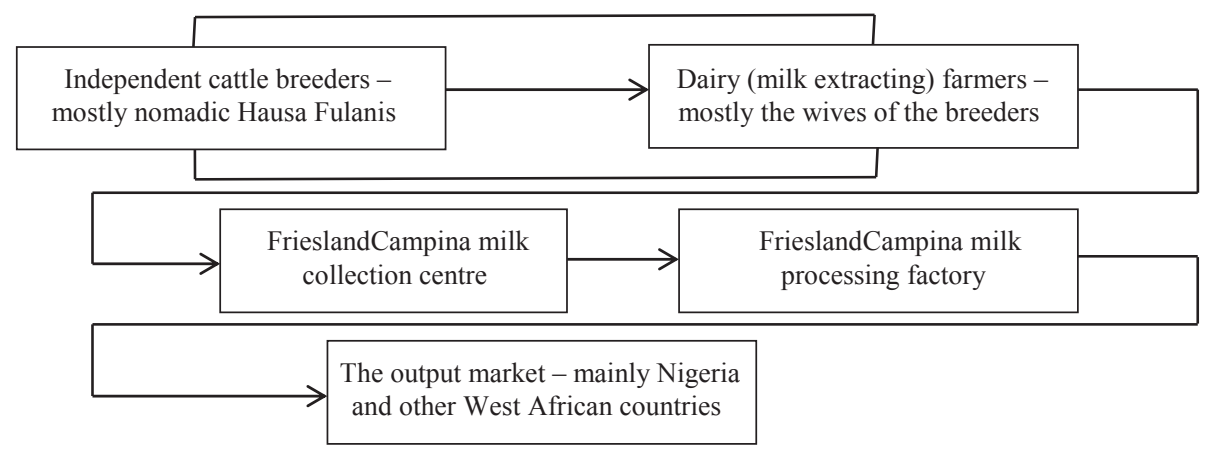

Figure 3. The dairy development programme model of milk collection and process.

The disaggregated nature of smallholder dairy farmers participating in the DDP reflects in the results of our survey, where the farm size of majority of the respondents range from 1 to 4 hectares with about 44\% holding less than one hectare and $27.5 \%$ holding between $1-2$ hectares (Table 3 ).

Although the DDP was designed only to provide technical support to the farmers (FCW, 2016), the inherent cost of transacting along such model remains enormous. To confirm this, FCW in its 2010 annual report (FCW, 2010) stated clearly that the DDP was 'an extremely challenging project as milk production in an industrial scale hardly exists in Nigeria.' As expected, effective implementation of the programme was hampered by the uncluttered nature of the dairy farmers. The fact that of the 102 farmers that participated in the survey, none owned more than 50 cows corroborates this claim.

The DDP was without some benefits, despite its failed attempt at integrating smallholder farmers into a mainstream national value chain. As shown in Table 2, milk collection and artificial insemination are found to be the most prominent elements of the DDP. The participating farmers perceived increased income, improved milk yields, and improved knowledge of dairy farming as the major benefits they have received from the DDP project.

In essence, government's support to the dairy farmers is almost non-existent, from the views of the farmers and responses generated from the focus group discussion. Where it exists, it is found to be highly unpopular. This is demonstrated by the fact that about $89 \%$ of the questionnaire respondents had no knowledge of any government agricultural policies nor benefitted from them. About $11 \%$ of the respondents had knowledge of the agricultural lending policy of the government, but indicated their inability to benefit from such facilities because of the rigidity of the processes involved.

It is important to note that the failure of the DDP is not because it was incompatible in the Nigerian context. It is more because of the technical defects in its design whereby its operations are concentrated outside of the mainstream cattle farming zones in the north. Although the programme enjoyed high degree of acceptability by the participating farmers, its sustainability was impaired by its clear lack of integration in the local dairy

Table 3. The distribution of farm size among the dairy farmers.

\begin{tabular}{lcc}
\hline Response & Number & Percentage \\
\hline Less than one hectare & 45 & 44.1 \\
Between 1-2 hectares & 28 & 27.5 \\
Between 2-4 hectares & 9 & 8.8 \\
Above 4 hectares & 6 & 5.9 \\
No response & 14 & 13.7 \\
Total & 102 & 100.0 \\
\hline
\end{tabular}


value chain. Responding to the question on their relationship with FCW, the farmers were in consensus of having a good relationship with and benefited from the DDP. But this was only to the extent that FCW could afford to carry them along - an option that is constrained by high transaction costs and is considered less viable than the lucrative import-dependency approach.

Rather than promoting DDP as a sustainable business model, FCW opted for the option of running it as though it is part of its CSR strategies. As reported by one of the officials of the company during the focus group discussion, FCW buys their milk from the participating smallholder farmers at premium above prevailing market prices. Although it maintained that purchasing of milk from the farmers under the DDP scheme transformed the social and economic status of the local farmers, it is unclear how such social strategy can be sustained in a long-run. Instead, the approach heightened the suspicion that the commitment of the company to the scheme was just another CSR strategy for regulatory manoeuvring. Existing evidence from a similar setting proved that indeed CSR could be applied as a strategy to minimize the influence of public regulation and promote customized regulatory actions (Horowitz, 2015). Applying a case study of oil companies in Angola, Wiig and Kolstad (2010) indicted CSR as a strategic tool used by MNCs to secure licenses and contracts, and by so doing facilitate patronage problems.

Given the inherent lapses in the above integration model, it was not surprising that FCW chose to consolidate on its milk importation, processing and marketing. Rather than continuing to invest in the developing the local diary industry, the company adapted marketing strategy to the local specificities and structure of milk demand in Nigeria, which allowed it to largely import its dairy raw materials from the Netherlands and process same into end products locally in Nigeria (Business Day, 2019). This is only made possible because the government took no concrete policy steps over the years to discourage the importation of semi-finished and finished dairy products.

\section{Conclusion and recommendations}

In this study, we triangulated information from mixed sources to explain the consequences of the spatial issues around dairy farming and milk production in Nigeria. The findings show no clear regulatory instruments in place to promote or protect the local dairy industry in the country. They show that the DDP, in its original design, betrayed the suspicion that it was a CSR stunt to quell local tension and possibly divert policy attentions from the quest for backward integration. The impact of the programme is equally shown to have been overwhelmed by non-visibility of government support, which made the participating cattle farmers more dependent on FCW. This is confirmed in the practice where the company has to buy local milk from participating farmers at a premium above the prevailing market prices.

The dairy industry in Nigeria remains dominated by few foreign players and foreign dairy products; it is largely dependent on imported dairy inputs; lacks any meaningful integration of local farmers and investors in the national dairy value chain; and above all, remains without any sustainable form of government incentives and support. While the situation remains as it is, FCW profits and dominates the entire industry - controlling up to $75 \%$ of the total market share. The local milk content of its milk production in Nigeria remains at an infinitesimal level of 3\%. The company continues to demonstrate that it has more incentive to support and lobby for the status quo than to push for policy and regulatory measures that support meaningful backward integration in the country. We find that for FCW, specifically, its preference for importation and persistent high dividend pay-out ratio combine to implicate the company in this conjecture. High dividend pay-out, leading to profit and capital repatriation, is also a form of rent-extraction. This, according to Fazekasa and Toth (2016) and Innes (2014), is a strong manifestation of the role of a state captor.

The foregoing dynamics can only change materially when government creates a conducive environment and/or when FCW gets involved in large scale dairy farming. We conclude along this line that although MNCs can help promote the development of local industries in host communities, the task of adopting and operationalizing effective indigenous industrial promotion policies and providing the support infrastructure 
is the responsibility of the host government and cannot be outsourced to foreign MNCs. Specifically, we recommend that for a sustainable backward integration to take place in the dairy industry in Nigeria, government should formulate and implement reasonable intervention schemes that ensure the provision of roads and water facilities, free healthcare for cattle, and creation of more milk collection centres to further ease dairy farming, improve yields and make milk collection and process easier. Given the rising rate of conflicts between herdsmen and local communities in most southern and north central parts of the country, a starting point (in the short term) will be for government to formulate a cattle farming and grazing policy that is acceptable to all the stakeholders in the downstream sector of the dairy industry. Creating a conducive atmosphere for cattle farming and local dairy production will then be followed with a long-term government policies that disincentivize importation and induce multi-stakeholder engagement in local dairy value chain development.

\section{Acknowledgements}

This research is part of a wider project on increasing the value of Dutch multinationals for national economies: a comparative study of Kenya and Nigeria. The project is part of the research agenda of the Knowledge Platform on Inclusive Development Policies, which is funded by the Dutch Ministry of Foreign Affairs through NWO-WOTRO (grant number W 08.370.105). Earlier versions of the paper were presented at the $6^{\text {th }}$ Annual Meeting of the African Economic History Network (Sussex, 21-22 October 2016) and the NWO-WOTRO Research Project Advocacy Meeting (Lagos, 26-27 January 2017). We thank participants for their constructive criticisms. Finally, we are grateful to Wijnand Klaver for his comments on an earlier draft of this paper. We thank the anonymous reviewers and the editors for their very insightful comments and suggestions. The usual disclaimers apply.

\section{References}

Acemoglu, D. and J. Robinson. 2010. The role of institutions in growth and development. Leadership and growth 1 (2): 1-33.

Adewale, A. R. 2017. Import substitution industrialisation and economic growth-evidence from the group of BRICS countries. Future Business Journal 3 (2): 138-158.

Akinnaso, N. 2018. The controversy over cattle colonies. Punch Newsletter. Available at: https:/punchng. com/the-controversy-over-cattle-colonies/.

Aqueveque, C., P. Rodrigo and I.J. Duran. 2018. Be bad but (still) look good: can controversial industries enhance corporate reputation through CSR initiatives? Business Ethics: A European Review 27 (3): 222-237.

Asiedu, E. 2002. On the determinants of foreign direct investment to developing countries: is Africa different? World Development 30 (1): 107-119.

Auty, R. M. 2007. Patterns of rent extraction and deployment in developing countries: implications for governance, economic policy and performance. In Mavrotas G., Shorrocks A. (eds) Advancing development. Studies in development economics and policy. Palgrave Macmillan, London, pp. 555-577.

Business Day. 2019. How Nigeria can bridge \$1.3bn annual dairy import. Available at: https://businessday. ng/agriculture/article/how-nigeria-can-bridge-1-3bn-annual-dairy-import/.

Carmody, P. 2017. The geopolitics and economics of BRICS' resource and market access in Southern Africa: aiding development or creating dependency? Journal of Southern African Studies 43 (S): 863-877.

Chagwiza, C., R. Muradian and R. Ruben. 2016. Cooperative membership and dairy performance among smallholders in Ethiopia. Food Policy 59: 165-173.

Coase, R.H. 1937. The nature of the firm. Economica 4: 386-405.

Deininger, K. and H.P. Binswanger. 1995. Rent seeking and the development of large-scale agriculture in Kenya, South Africa, and Zimbabwe. Economic Development and Cultural Change 43 (3): 493-522.

Dries, L., E. Germenji, N. Noev and J. F. M. Swinnen. 2009. Farmers, vertical coordination, and the restructuring of dairy supply chains in Central and Eastern Europe. World Development 37 (11): $1742-1758$. 
Dries, L. and J. Swinnen. 2004. Foreign direct investment, vertical integration, and local suppliers: evidence from the Polish dairy sector. World Development 32 (9): 1525-1544.

FAOSTAT. 2013. FAO world cattle inventory: ranking of 209 countries. Available at: http://beef2live.com/ story-world-cattle-inventory-ranking-209-countries-fao-247-127843.

FCW. 2010. Annual Report 2010. Royal FrieslandCampina N.V. Available at: https:/www.frieslandcampina. com/app/uploads/sites/2/2016/12/FrieslandCampina-Annual-Report-2010.pdf.

FCW. 2014. Annual report and financial statement 2014. FrieslandCampina WAMCO Nigeria Plc. Available at: https://s3-eu-central-1.amazonaws.com/fc-nigeria-prod/app/uploads/2015/07/FrieslandCampinaWAMCO-2014-Annual-Report.pdf.

FCW. 2016. FrieslandCampina WAMCO dairy development programme. Paper presented at the African Studies Centre Leiden NWO-WOTRO Funded Project. Workshop on productive employment and inclusive growth, 28 January 2016, Lagos, Portugal.

FrieslandCampina, 2011. Dairy development in Nigeria. Available at: https://www.frieslandcampina.com. ng/sustainability/dairy-development/.

FrieslandCampina. 2014. Annual Report 2014. Royal FrieslandCampina N.V. Available at: https://www. frieslandcampina.com/app/uploads/sites/2/2016/12/FrieslandCampina-Annual-Report-2014.pdf.

FrieslandCampina. 2015. Half-year report: major development. Royal FrieslandCampina N.V. Available at: https://www.frieslandcampina.com/app/uploads/sites/2/2015/08/FrieslandCampina-Half-yearreport-2015-hr.pdf.

FrieslandCampina. 2019. Dairy development programme. Available at: https://www.frieslandcampina.com/ en/sustainability/dairy-development-programme/.

Friesland Food WAMCO Nigeria Plc. 2000. Annual report and financial statement 2000. West Africa Milk Company, Plc., Lagos, Portugal.

Friesland Food WAMCO Nigeria Plc. 2005. Annual report and financial statement 2015. West Africa Milk Company Plc., Lagos, Portugal.

Geyskens, I., J.B.E. Steenkamp and N. Kumar. 2006. Make, buy, or ally: a transaction cost theory metaanalysis. Academy of Management Journal 49 (3): 519-543.

Gui-Diby, S.L. and M.F. Renard. 2015. Foreign direct investment inflows and the industrialization of African countries. World Development 74: 43-57.

Hennart, J.F. 1991. The transaction cost theory of the multinational enterprise. In: The nature of the transnational firm, $2^{\text {nd }}$ edition, edited by C.N. Pitelis and R. Sugden, Routledge, New York, NY, USA.

Herath, D. and A. Weersink. 2009. From plantations to smallholder production: the role of policy in the reorganization of the Sri Lankan tea sector. World Development 37 (11): 1759-1772.

Horowitz, L.S. 2015. Culturally articulated neoliberalisation: corporate social responsibility and the capture of indigenous legitimacy in New Caledonia. Transactions of the Institute of British Geographers 40 (1): 88-101.

Iamsiraroj, S. 2016. The foreign direct investment-economic growth nexus. International Review of Economics \& Finance 42: 116-133.

Ilu I. Y.; A. Frank and I. Annatte. 2016. Review of the livestock/meat and milk value chains and policy influencing them in Nigeria, Published by the Food and Agriculture Organization of the United Nations and the Economic Community of West African States, Rome. Available at: http://www.fao. org/3/a-i5259e.pdf.

Innes, A. 2014. The political economy of state capture in Central Europe. Journal of Common Market Studies 52 (1): 88-104.

Jansen, H. 1992. Dairy consumption in northern Nigeria: implications for development policies. Food Policy 17: 214-226.

Kapfer, S. 2006. Multinational corporations and the erosion of state sovereignty. Illinois State university conference for students of political science, 7 April 2006. Available at: https://pol.illinoisstate.edu/ downloads/conferences/2006/Kapfer2006.pdf.

Kilelu, C., L. Klerkx, A. Omore, I. Baltenweck, C. Leeuwis and J. Githinji. 2017. Value chain upgrading and the inclusion of smallholders in markets: reflections on contributions of multi-stakeholder processes in dairy development in Tanzania The European Journal of Development Research 29: 1102-1121. 
Lodge T. 2018. State capture conceptual considerations. In: State capture in Africa: old threats, new packaging, edited by M. Meirotti and G. Masterson, EISA, Johannesburg, South Africa.

Madhok, A. 1997. Cost, value and foreign market entry mode: the transaction and the firm. Strategic management journal 18 (1): 39-61.

McCulloch, N., N. Balchin, M. Mendez-Parra and K. Onyeka. 2017. Local content policies and backward integration in Nigeria. Available at: https:/www.odi.org/publications/10948-local-content-policiesand-backward-integration-nigeria.

Murigu, P., K. Njage, B. Opiyo, J. Wangoh and J. Wambui. 2018. Scale of production and implementation of food safety programs influence the performance of current food safety management systems: case of dairy processors. Food Control 85 (1): 85-97.

National Agency for Food and Drug Administration and Control (NAFDAC). 2018. Milk and dairy products regulations. Available at: https:/www.nafdac.gov.ng/food/food-regulations/.

North, D. C. 1984. Transaction costs, institutions, and economic history. Zeitschrift für die Gesamte Staatswissenschaft/Journal of Institutional and Theoretical Economics 1: 7-17.

Nwoko, S. 1988. The development of dairy imports in Nigeria. LPU Working Paper No.10. Addis Ababa, International Livestock Centre for Africa. Available at: https://core.ac.uk/download/pdf/132634718.pdf.

Okojie, J. 2018. How import duty reduction on powdered milk is hurting local manufacturers. BusinessDay. Available at: https://tinyurl.com/y2hq2uwc.

Omondi, I., E.J.O. Rao, A.A. Karimov and I. Baltenweck. 2017. Processor linkages and farm household productivity: evidence from dairy hubs in East Africa. Agribusiness 33 (4): 586-599.

Orji, S. 2018. Nigeria’s 'cattle colony' problem, Aljazeera. Available at: https://www.aljazeera.com/indepth/ opinion/nigeria-cattle-colony-problem-180128104645450.html.

Phelps, N.A. 2008. Cluster or capture? Manufacturing foreign direct investment, external economies and agglomeration. Regional Studies 42 (4): 457-473.

Poulton, C., J. Kydd and A. Dorward. 2006. Overcoming market constraints on pro-poor agricultural growth in Sub-Saharan Africa. Development policy review 24 (3): 243-277.

PricewaterhouseCoopers (PWC). 2017. Transforming Nigeria's agricultural value chain: a case study of the cocoa and dairy industries. Available at: https://www.pwc.com/ng/en/assets/pdf/transformingnigeria-s-agric-value-chain.pdf.

Punch Newspaper. 2016a. Food importation: Nigeria at risk of hunger, says Dangote. Available at: http:// punchng.com/food-importation-nigeria-risk-hunger-says-dangote/.

Punch Newspaper. 2016b. FrieslandCampina WAMCO. Available at: https://punchng.com/frieslandcampinawamco/.

Rao, E. J., I. Omondi, A.A. Karimov and I. Baltenweck. 2016. Dairy farm households, processor linkages and household income: the case of dairy hub linkages in East Africa. International Food and Agribusiness Management Review 19 (4): 95-108.

Sharma, S., H. Vredenburg and F. Westley. 1994. Strategic bridging: a role for the multinational corporation in third world development. Journal of Applied Behavoral Science 30 (4): 458-476.

Sutter, J.W. 1987. Cattle and inequality: herd size differences and pastoral production among the Fulani of northeastern Senegal. Africa 57 (2): 196-218.

Taylor, I. 2016. Dependency redux: why Africa is not rising. Review of African Political Economy 43 (147): $8-25$.

The Economist. 2015. Dairy farming in Nigeria: uncowed. Middle East African Edition. Available at: https:// www.economist.com/middle-east-and-africa/2015/06/06/uncowed.

Udofia, O.E. 1984. Imperialism in Africa: a case of multinational corporations. Journal of Black Studies 14 (3): 353-368.

Wang, H.; H. Yu and B. Lid. 2017. Is dairy complex a solution to milk safety? A comparison of farmers' perceived and realized food safety effects. International Food and Agribusiness Management Review 20 (4): 605-613.

WAMCO. 1997. Annual report and financial statement. West Africa Milk Company, Lagos. 
Wiesner, E. 2017. Transaction cost economics and public sector rent-seeking in developing countries: toward a theory of government failure. In: Evaluation and development: the institutional dimension, edited by R. Picciotto and E. Wiesner, Routledge, New York, NY, USA.

Wiig, A. and I. Kolstad. 2010. Multinational corporations and host country institutions: a case study of CSR activities in Angola. International Business Review 19 (2): 178-190.

Williamson, O.E. 1981. The economics of organization: the transaction cost approach. American journal of sociology 87 (3): 548-577.

Zhu, B. 2017. MNCs, rents, and corruption: evidence from China. American Journal of Political Science 61 (1): 84-99. 
